\title{
AN ASSESSMENT OF THE INNOVATIVENESS OF FIRMS IN NIGERIA'S PETROLEUM SECTOR
}

\author{
G.M. Bubou ${ }^{1 * \#} \&$ J.E. Amadi-Echendu ${ }^{1}$
}

\section{ARTICLE INFO}

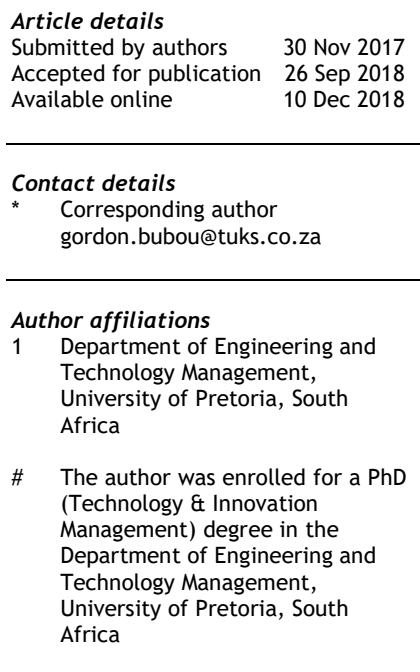

DOI

http://dx.doi.org/10.7166/29-4-1881

\begin{abstract}
A firm's level of innovativeness is regarded as an indicator of its creativity, competitiveness, and performance. An understanding of the processes that lead to innovativeness is therefore crucial to scholars and practitioners. This makes innovativeness assessment a necessity, especially for firms. Perplexingly, there are few innovativeness studies on resource-intensive industrial sectors, such as petroleum, in African countries. This paper is a contribution to filling the knowledge gap. The study used item means to analyse data from a cross-sectional survey. The findings show that, while overall the petroleum firms were barely innovative, they performed better in terms of the non-technological aspects of innovativeness.
\end{abstract}

\section{OPSOMMING}

'n Firma se vlak van innovasie word as 'n aanduiding van sy kreatiwiteit, kompeterendheid en vertoning geag. Die begrip van die prosesse wat lei tot innovasie is dus krities vir navorsers en praktisyne. Dit maak innovasie assessering 'n noodsaaklikheid, veral vir firmas. Tog is daar min studies wat die innovasievlak in hulpbron intensiewe industrieë, soos die petroleum-industrie, in Afrika. Hierdie artikel probeer om dié leemte aan te spreek. Die studie het data van 'n deursnitpeiling gebruik en die bevindinge toon dat, alhoewel petroleumfirmas beswaarlik innoverend was, hulle beter gevaar het in terme van die nie-tegnologiese fasette van innovasie.

\section{INTRODUCTION AND PROBLEM BACKGROUND}

\subsection{Introduction}

An overarching firm-wide innovation capability structure, referred to as 'innovativeness', is now regarded as the defining factor in the long-term survival of firms [1], even though innovation is viewed as a strategic competence of an organisation and as one of the most vital factors that empowers firms to retain their competitive position ([2] [3] [4] [5] [6] [7] [8] [9] [10]). In fact, Walsh, Lynch and Harrington [1] assert that the long-term survival of firms depends more on their overall strategic-level innovativeness and less on the actual innovations themselves. Thus, more than ever before, firms must exploit their innovativeness to develop either new businesses or business models successfully, to confront the challenges [2] of the ever dynamic and turbulent business environment. Similarly, technological progress (of countries, nations, or regions) stems from the build-up of innovative activities [11]. For this reason, firm innovativeness has become an issue of major importance in the quest to produce companies that are more creative, efficient, competitive and, most importantly, healthy in the long term [12]. Given the importance of innovativeness in the modern economy, firms are continuously looking for ways to use it for the effective management of innovations [6].

Understanding the processes that lead to innovativeness is crucial to academia, industry [13] [14], and policymakers alike, and thus the assessment of innovativeness at both the firm and the level of the economy has become necessary. This is because, when firms understand their innovativeness process, they will be able to manage it and so increase their return on investment in innovation [15]. 


\subsection{Problem statement}

Despite the emergence of non-conventional and alternative energy sources, the oil and gas industry continues, and will continue, to play a fundamental role in the global economy for some years to come. Nigeria, a contender for the position of Africa's largest economy, has continued to occupy the continent's topmost oil and gas exporter position, even though she was challenged by Angola during heightened militancy in the Niger Delta region. The petroleum sector has been of strategic importance to Nigeria because oil is still largely the mainstay of that economy. For instance, as a share of the economy, the oil sector represented 7.15 per cent of total real GDP in 2016 [16], and oil receipts dominate fiscal revenue and exports [17], and the oil and gas industry remains the biggest source of foreign exchange earnings [18]. Thus innovation studies of this critical sector are of the utmost importance.

The innovation process itself is generally accepted to be a locally embedded process [19], and is a highly context-dependent concept. Likewise, innovativeness measurement systems need to be institutionalised within a firm's management systems. However, most of what is in the literature concentrates on the developed economies, and there is little, or next to nothing, published on innovativeness in the petroleum sector of African economies. The knowledge gap identified above has implications for innovation studies and policy, because a failure to address it risks neglecting the democratisation of innovation studies, which are supposed to be inclusive of diverse regions and economies and embrace all industrial sectors [20].

\subsection{Aim of the study}

The main aim of the study was to attempt to fill the knowledge gap identified in the previous section. The research thus aims to fulfil the following objectives: to investigate the overall firm innovativeness of the study context (petroleum companies in Nigeria); and to determine whether the sampled firms were more technologically innovative than administratively innovative.

By providing insights into the overall firm innovativeness of enterprises from resource-intensive industrial sectors such as the petroleum sector of an African country (in this case, Nigeria), this research departs from previous works on innovativeness, which mostly consist of works from advanced countries, with a few exceptions from some emerging economies. This further expands the growing body of research on innovation, innovativeness and its measurement, and organisational theory (as the study employs organisations as the unit of analysis). Using both subjective and objective approaches to innovativeness measurement, the study uses data from a cross-sectional survey based on a researcher-designed instrument that was adapted from different frameworks. The study included 12 firms in the petroleum sector of Nigeria's economy.

The rest of the paper is arranged thus: Section 2 briefly presents prior related studies. Section 3 describes the research approach and methods to be adopted. Discussions of analysis are made, conclusions are finally drawn, and limitations and directions for future research are highlighted in Section 5.

\section{THEORETICAL REVIEW AND MEASUREMENT FRAMEWORK}

In this section, the concept of innovativeness is discussed in detail, and the different innovativeness typologies akin to the types of innovation are presented. The section also reviews previous innovativeness measurement frameworks, and examines arguments that support the need for the development of innovativeness measurement indicators that are considered suitable for developing countries' contexts.

As stated earlier, it is well documented that innovativeness has a positive relationship with firms' business performance [21] and, indeed, is viewed as a significant indicator of superior performance and effective organisational outcomes [22] [23] [24] [25]. Of course, a truly innovative firm exhibits innovative behaviour consistently over time, and possesses the potential to improve business processes and outcomes [26], and thus performs better than those that are not [3] [12]. Innovativeness allows firms to evolve continuously, despite the dynamism in the modern business climate [23]; equally, it empowers companies regularly to improve or modify their manufacturing methods or products, which in turn intensifies their competitive edge [27]. It has thus become an 
essential tool for growth strategies for entering new markets and for improving market share [2] [28].

\subsection{Defining innovativeness}

According to Therin [29], innovativeness represents the capacity of a firm to innovate. Innovativeness was defined as the degree to which an individual or other unit of adoption adopts new ideas relatively earlier than others in a system [30]. Similarly, it has been argued that innovativeness refers to the number of innovations successfully implemented [31] by an adopting unit. However, Gilbert [3] considers innovativeness as encompassing "the concepts of newness in systems, processes, products and services, behavioural change, environmental adaptation, and learning and knowledge development; all of which occurs in context over time" (p. 3).

Given the above, the units of adoption can be firms (or even departments within firms), the public sector [32], nation states, or regions. Equally, 'systems' could mean firms within an industrial sector, such as the petroleum sector, or among industries [33]. It thus implies that those firms (in this case, petroleum firms in Nigeria) that adopt innovative ideas or concepts (or even technology) earlier than other firms (or implements more innovations than others) are considered innovative [33].

\subsection{Innovativeness typologies}

Chye et al. [34] classify innovativeness in terms of whether it is technology-, behavioural-, or product-based. Technology-based innovativeness indicates a firm's readiness to accommodate technological changes. Behavioural-based innovativeness describes the behavioural dynamics that relate to the speed with which new ideas are generated or accepted. Product-based innovativeness describes an organisation's proclivity to try new products and services. Technology-related innovativeness is one in which firms demonstrate their willingness to exploit business opportunities arising from technological dynamism [34]. Here, 'technological innovativeness' is operationally defined as the propensity of a firm to develop a technological innovation quickly, or to adopt existing technological innovations relative to others.

On the other hand, non-technological or administrative innovativeness takes place in societal or institutional networks, such as new markets or industrial structures [35], or in new solutions implemented in the management process, methods, or structure [36]. Kraśnicka, Gtód and WronkaPośpiech [36] regarded administrative innovativeness as the manifestation of the innovativeness of top management in their ability to engender, modify, adapt, and initiate new solutions in an organisation's management.

Over time, 'innovativeness' in the literature has assumed the following typologies: product innovativeness, process innovativeness, market innovativeness, organisational innovativeness, and strategic innovativeness. These are explained further in subsequent sub-sections. The Oslo Manual combined the first two to form the technological innovativeness category, and the remaining three - marketing, organisational, and strategic innovativeness - form the non-technological innovativeness category [37], otherwise called 'administrative innovativeness'.

Product innovativeness: Wang and Ahmed [22] consider product innovativeness to be a significant dimension. While product innovativeness maintains a central focus of product newness, market innovativeness emphasises the novelty of market-oriented approaches. Although they are treated as salient factors, product and market innovativeness are inevitably inter-twined [23]. By contrast, Ettlie et al. in Garcia and Calantone [38] emphasise that product innovativeness does not equate to firm innovativeness. Similarly, Garcia and Calantone [38] argue that the innovativeness of a product that a firm adopts or markets is not a measure of organisational innovativeness. Product-related innovativeness reveals an organisation's proclivity to trying new products and services (Foxall in Chye et al. [34]). Similarly, combining different scholarly perspectives, Dilek [39] refers to it as "the novelty and meaningfulness of new products introduced to the market in a timely fashion".

Process innovativeness: According to Wang and Ahmed [22], process innovativeness is sometimes confused with technological innovativeness, and so is evaluated as a sub-unit of technological innovativeness. Dilek [39] explains that process innovativeness captures the introduction of new manufacturing methods, new management models, and new technology that can be used to improve manufacturing and management processes. He maintains that process innovativeness is vital to the 
overall innovative capability, in that an organisation's ability to harness materials and capabilities - but, most importantly, its ability to recombine and transform its resources and abilities to meet the requirement of creative production - is crucial to organisational success. To innovate along this dimension, an enterprise can restructure its methods for better efficacy and quality or shorter throughput [40]. Sawhney, Wolcott and Arroniz [40] add that changes could lead to the relocation of an organisation's processes or the decoupling of its front end from its back end.

Market innovativeness: this type of innovativeness is described as the scope of activities undertaken to market a product or services [41]. Andrews and Smith [41] maintain that market innovativeness represents considerable differences from marketing practices in the product category. They maintain that, in broad terms, it incorporates innovation associated with market research, adverts, and publicity stunts. In their view, market innovativeness enables firms to avert competitive parity through the continuous development of marketing initiatives. The authors [41] also note that initiatives not only consist of alterations to the physical product, but also include changes to other parameters such as packaging, tagging, positioning, etc. However, market innovativeness is referred to as the novelty of methods that firms adopt to enter and harness targeted markets [23] [39]), while underscoring the novelty of market-oriented tactics [23]. And, for some firms, this means entering new markets or identifying niche markets, and offering the current products by using new marketing strategies to promote the products and services. Atuahene-Gima, Li and De Luca [42] list some marketing strategic innovativeness practices, including the use of new packaging; new techniques and channels of distribution; new advertising modes and content; and creative pricing and payment options.

Organisational innovativeness: according to Rogers [30], organisational (or behavioural-related innovativeness) models a more dynamic organisational behaviour in terms of the speed of the firm in generating or accepting new ideas relative to others. Also, firms operating in this modern dynamic business environment will require dynamic organisational structures. Such structures enable firms to respond more quickly to market changes [43] and to be flexible enough to adapt to, or keep pace with, current industry trends. Hence organisational innovativeness also entails efforts geared towards establishing and maintaining an organisational structure that will foster innovativeness within a firm [6].

Strategic innovativeness: some scholars regard sound and innovative strategy and good stakeholder management that are innovation-oriented as a necessity for organisations that want to be innovative [44]. According to Dilek [39], strategic innovativeness did not receive as much attention as the other innovativeness factors in the literature. He maintains that strategic innovation is important because it can take a firm from the bottom and carry it to the top position by careful tactics. Besanko et al., in Dilek [39], define strategic innovation as the formulation of new strategies that increase competitive advantage and create value for the firm.

\subsection{Firm innovativeness measurement framework}

Organisational innovativeness has become a part of organisations' activity plans and an integral element in their future success and competitive advantage [9]. For example, Boly et al. [14] assert that tools for measuring innovation enable managers to plan, define, and communicate innovation strategies, and to monitor progress and learning. The conclusions of a study on firm executives by James et al. [45] was that companies should rigorously track innovation as a core business operation.

In fact, a good firm's innovativeness measurement system fosters better management of the innovation process, helping managers to make informed decisions; and such measurement metrics also affect behaviour by helping to align goals and actions with the best interests of the firm [9]. Consequently, the need to measure firm innovativeness has been underscored by practitioners from industry [9]. For instance, Boly et al. [14] submit that firms must regularly monitor the suitability of their innovation management actions and the resources dedicated to these actions.

In their study on the innovativeness factors of the Iranian automotive industry, Vafaei, Shakeri and Owlia [21] identified and extracted from the literature some intervening components in organisational innovation or internal innovation factors, and elements such as those within the four dimensions of strategy of innovation, job satisfaction, interest in organisational innovation, and atmosphere. The model aggregated the four internal innovation factors into what they refer to as the 'effective innovativeness' factors, although the effectiveness factors themselves are 
aggregations of measurement elements in a framework of 59 entries. Similar to the model mentioned above, Duygulu and Özeren [24] also try to determine the factors affecting firms' innovativeness from the perspective of leadership styles and organisational culture.

In similar vein, Wong and Fung [46] state that three aspects measure the innovativeness of organisations. While Nystrom et al., in Wong and Fung [46], measured innovativeness in terms of the degrees of the radicalness of adopted innovations, the relative advantage of adopted innovations, and the number of adopted innovations, in a related development, Subramanian and Nilakanta, in Wong and Fung [46], measured innovativeness in terms of the number, timing, and consistency of the innovation adoptions. From this, Wong and Fung [46] concluded that, except for the measurement of the number of adopted innovations, the other measurements are different. This then suggests that there may be five possible aspects to consider when measuring innovativeness.

Based on the operational definition provided earlier, the proposed framework will approach the determination of the technological innovativeness of firms from two different perspectives. One way will be to investigate how quickly firms either introduce new technological innovations or adopt technological innovations, in relation to others. The other will look at technological innovativeness from the perspective of the propensity of petroleum firms to innovate.

Based on the models seen so far, the dimension introduced by Wong and Fung [46] seems to tally with the operationally provided definition, as it addresses issues of agility, degree of newness, and number of adopted innovations. Therefore, the proposed model will consider the assessment of innovativeness of the petroleum sector in terms of five innovativeness typologies using the following aspects: degree of radicalness of innovation; frequency of adoption of innovation; time of adoption; and consistency of innovation adoption.

The metrics adopted were based on the analytical hierarchical process (AHP) framework of Wu [47] to aggregate innovativeness indicators into five hierarchical levels. Works by Jain, Siddiquee and Singal [48] also used an AHP-based method to measure the innovativeness of an organisation. According to Stone et al. [49], the aggregate index approach is one of two approaches in which numerous factors are combined or integrated to form the overall innovation score or index. This aggregate index approach is frequently used by governments, policymakers, and others to evaluate the level of innovation within a nation, a region, and even a firm [49]. This model was based on the knowledge of the innovation process and evaluating the aspects that play a critical role in innovation. Similarly, our metrics adapt some of the indicators of Bigliardi, Colacino and Dormio [50], and those of Laforet and Tann [51]. Accordingly, every dimension consists of three or four subdimensions, all of which are measured by at least two to, at most, eleven metrics. All the metrics have been proposed and applied in previous research that was relevant to firm innovativeness (see the research framework in Figure 1). The process of measurement scale development has been previously explained in detail by Bubou and Amadi-Echendu [52].

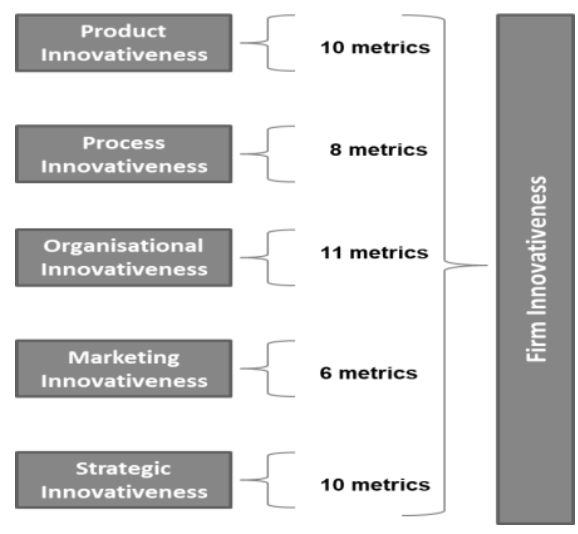

Figure 1: Measurement framework 


\subsection{Research methods}

To assess the innovativeness of the petroleum firms, we adopted a cross-sectional survey approach. This seems to be one of the most frequently adopted approaches in the measurement of innovations metrics, because surveys capture a wide range of indicators [20]. Also, innovation surveys in latecomer countries, if appropriately adjusted, are useful in innovation policy formulation and implementation [53].

A purposive sample of fifty firms was selected from a sampling frame, the Directory of Nigeria Oil and Gas Industry - 2011 edition, which contains 565 petroleum firms operating in the Nigerian petroleum sector. This frame is by no means exhaustive; nevertheless, it contains all types of firms, including all oil majors. These are companies that voluntarily register with the Directory. Because of the nature of the sector's importance to Nigeria, the process of securing academic data from firms in its oil and gas industry is quite cumbersome. Added to that is the unwillingness on the part of oil firms either to participate in surveys, or to volunteer information when approached. These limitations guided the choice of sampling technique, and explain the reason for the small sample. Nonetheless, it is logically assumed that the purposive sample taken was representative of the population [20]. We collected data with the aid of questionnaires that were hand-delivered to the physical addresses of the firms.

\subsubsection{The survey instrument}

The survey instrument - a questionnaire, provided in Appendix 1 - was derived through a rigorous process of development that is explained in much more detail by Bubou and Amadi-Echedu [20]. In all, the questionnaire consisted of 54 items. Ten items related to product/service innovativeness; nine items related to process innovativeness; twelve items measured organisational innovativeness; while thirteen items and four items related to the measurement of market innovativeness and strategic innovativeness respectively.

\subsubsection{Measurement scale}

An ordinal scale of 0 to 6 was adopted for questions 1, 2, 11, 12, 13, and 20, with ' 6 ' representing intense innovativeness. Similar patterns were replicated for the other sections in the questionnaire. The higher frequency of 'once a year' was assigned a scale of 6 and 0 for 'none in 10 years' in the case of Questions 1 and 2. Likewise, the highest value of 6 was allotted to 'twice-a-year' and the value 0 was allocated to 'none in the last five years'. For the 'Yes', 'No', or 'Can't say' responses, a 'Yes' answer scores 1 , a 'No' answer scores 0 , and 'Can't say' was assigned zero for the purposes of computational convenience.

\section{RESULTS AND DISCUSSIONS}

The response rate to the survey was dismal. In fact, petroleum firms were unwilling to respond to the survey, and so only thirteen questionnaires were returned out of the fifty that were distributed. One of the returned questionnaires was not completed and so could not be used for any analysis. It was interesting, although not encouraging, to note that this was the only questionnaire to be returned through the official channels from one of the oil majors. The rest were completed mainly by former colleagues of the researcher who work in the oil and gas industry.

\subsection{Results of the innovativeness measures}

Product/service innovativeness scores: Table 1 shows the scores of the product innovativeness measurement of the petroleum sector of Nigeria as supplied by the respondents. 
Table 1: Product/service innovativeness scores

\begin{tabular}{|l|}
\hline S/N Question \\
\hline 1 How often does your firm introduce new product/service to the market? \\
\hline 2 How frequent does your organisation modify design of its product(s)/service(s)? \\
\hline 3 During the last two years, did your firm introduce any new or significantly improved product/service? \\
\hline 4 Was the product mainly developed by your company? \\
\hline 5 Was the product developed with other firms? \\
\hline 7 Where the products/services new to your firm? \\
\hline 8 Where your products/services new to the market? \\
\hline 9 Products introduced to your firm during the last two years wer products unchanged or only maarginally modified \\
\hline Sub-total \\
\hline
\end{tabular}

\begin{tabular}{l|l|l|l|l|l|l|l|l|l|l|l} 
F1 & F2 & F3 & F4 & F5 & F6 & F7 & F8 & F9 & F10 F11 F12 & $\bar{X}$
\end{tabular}

\begin{tabular}{|l|l|l|l|l|l|l|l|l|l|l|l|r|}
\hline 4 & 4 & 6 & 2 & 6 & 5 & 4 & 5 & 2 & 4 & 5 & 2 & 4.083333333 \\
\hline $\mathbf{5}$ & 4 & 6 & 2 & 5 & 5 & 2 & 5 & 2 & 5 & 2 & 2 & 3.75 \\
\hline 1 & 1 & 1 & 1 & 1 & 0 & 0 & 1 & 0 & 0 & 1 & 0 & 0.58333 \\
\hline 1 & 0 & 1 & 0 & 1 & 0 & 0 & 0 & 0 & 1 & 1 & 0 & 0.41667 \\
\hline 0 & 0 & 0 & 0 & 0 & 0 & 0 & 1 & 0 & 0 & 1 & 0 & 0.16667 \\
\hline 1 & 1 & 0 & 1 & 1 & 0 & 0 & 1 & 0 & 0 & 1 & 0 & 0.5 \\
\hline 1 & 0 & 1 & 0 & 1 & 0 & 0 & 1 & 0 & 0 & 0 & 0 & 0.33333 \\
\hline 0 & 1 & 1 & 1 & 0 & 0 & 0 & 0 & 0 & 1 & 0 & 0 & 0.33333 \\
\hline 13 & $\mathbf{1 1}$ & $\mathbf{1 6}$ & $\mathbf{7}$ & $\mathbf{1 5}$ & $\mathbf{1 0}$ & $\mathbf{6}$ & $\mathbf{1 4}$ & $\mathbf{4}$ & $\mathbf{1 1}$ & $\mathbf{1 1}$ & $\mathbf{4}$ & $\mathbf{1 0 . 1 6 6 6 6 7}$ \\
\hline
\end{tabular}

Using the adopted scale described above, and assuming that a firm scores 6 on Question 1 (introduced or adopted innovation at least once a year); scores 6 for Question 2 (modifies or redesigns products/service at least once a year); and answers yes for Questions 3 to 9; then the highest possible product/service innovativeness score of such a hypothetical firm would have been 18. But out of that possible highest score of 18 for product/service innovativeness, the sample scored 10.17, as shown in Table 1. The results further revealed that respondents were barely innovative in product/service innovativeness. Nevertheless, two firms, F3 and F5, performed exceedingly well, scoring 16 and 15 respectively. Firms F1 and F8 also performed well, scoring 13 and 14 points respectively. However, in general terms, with regard to product innovativeness, 58 per cent of the firms introduced a new or significantly improved product/service, while 50 per cent of the responding firms indicated that such a product/service was new to the firm. Item 10 in the research instrument, about the percentage of a firm's turnover in 2013 from products introduced in 2012 and 2013, was discarded because none of the respondents from the sample attempted it.

Process innovativeness scores: Table 2 displays the process innovativeness scores obtained from the respondents to the survey.

Table 2: Process innovativeness scores

\begin{tabular}{|c|c|c|c|c|c|c|c|c|c|c|c|c|c|c|}
\hline $\mathrm{S} / \mathrm{N}$ & Question & F1 & F2 & F3 & F4 & F5 & F6 & F7 & F8 & F9 & F10 F & & F12 & $\bar{x}$ \\
\hline & How frequent does your company review its operating processes? & 3 & 5 & 6 & 4 & 4 & 3 & 3 & 4 & 1 & 1 & 5 & 3 & 3.5 \\
\hline 12 & How often does your company change its opperating procedures? & 3 & 0 & 4 & 3 & 4 & 1 & 4 & 4 & 1 & 1 & 0 & 3 & 2.333333333 \\
\hline 13 & How often does your firm invest in new methods and firmware for its operations? & 1 & 5 & 5 & 1 & 4 & 1 & 4 & 4 & 1 & 1 & 1 & 3 & 2.583333333 \\
\hline 14 & During the last two years did your firm introduce new or significantly improved methods of manufacturing...? & 1 & 1 & 1 & 1 & 1 & 0 & 1 & 0 & 0 & 0 & 0 & 0 & 0.5 \\
\hline 15 & In the same period, did your firm introduce any new or significantly improved logistics or distribution methods...? & 1 & 0 & 1 & 1 & 0 & 0 & 1 & 0 & 0 & 1 & 0 & 0 & 0.416666667 \\
\hline 16 & During the years 2012 to 2013 , did your company introduce new or significantly improved supporting activities...? & 1 & 1 & 0 & 1 & 0 & 0 & 1 & 0 & 0 & 1 & 1 & 1 & 0.583333333 \\
\hline 17 & Was the process innovation mainly developed by your company or group of companies? & 1 & 0 & 0 & 0 & 0 & 0 & 0 & 0 & 0 & 0 & 0 & 0 & 0.083333333 \\
\hline 18 & was the process innovation developed with other firms or institutions? & 1 & 0 & 1 & 0 & 0 & 0 & 0 & 0 & 0 & 0 & 1 & 0 & 0.25 \\
\hline 19 & Or was it mainly developed by other firms or institutions? & 0 & 1 & 0 & 1 & 0 & 0 & 0 & 0 & 0 & 0 & 0 & 1 & 0.25 \\
\hline & Sub-total & 12 & 13 & 18 & 12 & 13 & 5 & 14 & 12 & 3 & 5 & 8 & 11 & 10.5 \\
\hline
\end{tabular}

Using a similar analysis to the one described earlier, out of a possible score of 24 for process innovativeness, the combined group mean score (as indicated in Table 2 ) was 10.50, which is less than 50 per cent of the possible highest score. However, seven firms - that is, more than half of the responding firms - scored 12 points or above; that is, they scored half or more of the total possible score. Four firms admitted that they reviewed their operating processes at least once every three years; another four firms reviewed theirs once in two years. One firm reviewed its operating processes once a year, and another firm twice a year. The remaining two firms reviewed their operating processes only once in five years. Similarly, seven of the twelve responding firms changed their operating procedures once in three years. About 50 per cent of the firms introduced new or significantly improved methods of manufacturing.

Organisational innovativeness was measured using scores obtained from questions 20 to 31 of the research instrument, as indicated in Table 3. 
Table 3: Organisational innovativeness scores

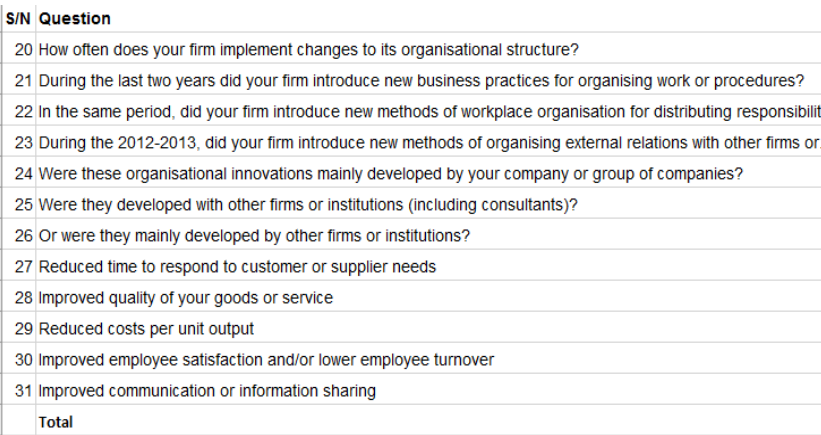

Table 3 reveals that 83 per cent of the sampled firms reported changing their organisational structures within the last five years. Among those firms that changed their organisational structures, four changed theirs at least once within the last two years, while one had done that within the previous year. About 75 per cent of the firms reported introducing new business practices for organising work. A similar proportion of firms indicated that they had introduced new methods of workplace organisation for distributing responsibilities. Likewise, about 67 per cent of responding firms indicated introducing new methods of organising external relationships with other firms or public institutions during the two years prior to the survey. Equally, 50 per cent of the respondents affirmed that the organisational innovations were mainly developed by their companies.

With regard to the impact of some of the organisational activities, improved communication among management, units, and employees had the greatest impact, as 75 per cent indicated high impact. This was followed by improved employee satisfaction and improved quality of goods/services. However, reduced time to respond to customers' or suppliers' needs had the least impact on organisational innovativeness. This should be a source of concern, since both customers and suppliers are crucial to the survival of any firm.

Market innovativeness measures were drawn from the market innovation scores extracted from the respondents in questions 32 to 45 of the survey instrument used for the study.

Table 4: Market innovativeness scores

\begin{tabular}{|c|c|c|c|c|c|c|c|c|c|c|c|c|c|}
\hline S/N Question & F1 & F2 & F3 & F4 & F5 & F6 & F7 & F8 & F9 & F10 F & 11 & F12 & $\overline{\mathrm{x}}$ \\
\hline 32 How often does your company implement changes to marketing concepts? & 4 & 5 & 6 & 4 & 4 & 3 & 4 & 4 & 1 & 4 & 1 & 1 & 3.41667 \\
\hline 33 How many new markets has your firm entered in the past five years? & 3 & 2 & 3 & 1 & 2 & 1 & 1 & 2 & 1 & 2 & 2 & 1 & 1.75 \\
\hline 34 During the last two years did your firm introduce new significant changes to the packaging of goods or services...? & 1 & 0 & 0 & 0 & 1 & 0 & 1 & 1 & 0 & 1 & 1 & 0 & 0.5 \\
\hline 35 In the same period, did your firm introduce new media or techniques of product promotion ..? & 1 & 0 & 0 & 1 & 1 & 0 & 0 & 1 & 0 & 1 & 1 & 0 & 0.5 \\
\hline 36 During the years 2012-2013, did your firm introduce new methods for product placement or sales channels ...? & 1 & 0 & 0 & 0 & 1 & 0 & 0 & 1 & 0 & 0 & 1 & 0 & 0.33333 \\
\hline 37 During the same period, did your firm introduce new methods of pricing goods or services ...? & 0 & 0 & 0 & 0 & 1 & 0 & 0 & 1 & 0 & 0 & 1 & 0 & 0.25 \\
\hline 38 Were these marketing innovations mainly developed by your company or group of companies? & 1 & 0 & 1 & 0 & 1 & 0 & 0 & 0 & 0 & 0 & 1 & 0 & 0.33333 \\
\hline 39 Were they developed with other firms or institutions (including consultants)? & 1 & 0 & 1 & 0 & 0 & 0 & 0 & 1 & 0 & 0 & 1 & 0 & 0.33333 \\
\hline 40 Or were they mainly developed by other firms or institutions (including consultants)? & 0 & 0 & 0 & 0 & 0 & 0 & 0 & 1 & 0 & 0 & 0 & 0 & 0.08333 \\
\hline 41 Increased or maintained market share & 3 & 2 & 3 & 2 & 3 & 2 & 2 & 2 & 0 & 1 & 3 & 3 & 2.16667 \\
\hline 42 Introduced products to new markets or customer groups & 3 & 1 & 3 & 3 & 3 & 1 & 2 & 2 & 0 & 2 & 3 & 3 & 2.16667 \\
\hline 43 Reduced costs per unit output & 2 & 0 & 0 & 3 & 3 & 1 & 3 & 0 & 0 & 2 & 3 & 3 & 1.66667 \\
\hline 44 Increased visibility of products or business & 3 & 1 & 2 & 3 & 3 & 1 & 2 & 2 & 0 & 2 & 3 & 3 & 2.08333 \\
\hline 45 Improved ability to respond to customer needs & 2 & 1 & 3 & 2 & 3 & 2 & 3 & 2 & 0 & 2 & 2 & 3 & 2.08333 \\
\hline Total & 25 & 12 & 22 & 19 & 26 & 11 & 18 & 20 & 2 & 17 & 23 & 17 & 17.6667 \\
\hline
\end{tabular}

The results from Table 4 indicate that all of the responding firms had implemented changes in their marketing concepts at least once in the past five years. However, eight out of the twelve firms implemented those changes quite frequently. For instance, as many as six of the firms claimed to have done this once in two years; one implemented such changes once a year; and the remaining one had done that twice within a year. All of the firms also claimed to have entered a new market within the last five years. For product packaging, new methods of product promotion, sales channels, product pricing, etc., the firms performed well enough, as indicated in the table. The table also reveals that increased or continuous maintenance of market share was of high importance to the 
firms investigated. Likewise, the introduction of products to new markets or customer groups was very important to the firms.

Strategic innovativeness scores: Questions 46 to 49 on the research instruments tackled questions relating to the strategic innovativeness of the firms studied. The results are shown in Table 5.

Table 5: Strategic innovativeness scores

\begin{tabular}{|c|c|c|c|c|c|c|c|c|c|c|c|c|c|c|}
\hline$S / N$ & Question & F1 & F2 & F3 & F4 & F5 & F6 & F7 F & F8 $\mathrm{F}$ & F9 & F10 F & F11 F & F12 & $\overline{\mathrm{x}}$ \\
\hline & 5 Does your firm has a writen strategic plan? & 1 & 1 & 1 & 1 & 1 & 1 & 1 & 1 & 1 & 1 & 1 & 1 & 1 \\
\hline 47 & How often does your firm review its vision, mission and strategic objectives? & 2 & 6 & 6 & 3 & 5 & 0 & 2 & 2 & 2 & 2 & 1 & 2 & 2.75 \\
\hline 48 & 3 How often has your company initiated new competitive strategies within the past five years? & 2 & 6 & 5 & 2 & 5 & 2 & 2 & 2 & 2 & 2 & 2 & 2 & 2.833333333 \\
\hline \multicolumn{2}{|r|}{49 How many new strategies have your company introduced to effect change(s) in its overall corporate strategy in the } & \multirow[b]{2}{*}{3} & \multirow[b]{2}{*}{3} & \multirow[b]{2}{*}{2} & \multirow[b]{2}{*}{1} & \multirow[b]{2}{*}{2} & \multirow[b]{2}{*}{3} & \multirow[b]{2}{*}{1} & \multirow[b]{2}{*}{2} & \multirow[b]{2}{*}{1} & \multirow[b]{2}{*}{3} & \multirow[b]{2}{*}{2} & \multirow[b]{2}{*}{0} & 1.916666667 \\
\hline & past five years? & & & & & & & & & & & & & \\
\hline & Total & 8 & 16 & 14 & 7 & 13 & 6 & 6 & 7 & 6 & 8 & 6 & 5 & 8.5 \\
\hline
\end{tabular}

All respondents indicated that their firms had written strategic plans. The results further revealed that, except for one firm, every responding firm reviewed its vision, mission, and strategic objectives. Some did this as often as once every year.

\subsection{Discussion of findings}

Here we discuss the findings from the study, and give evidence as to whether the aim of the study was achieved. Combining the item mean scores from Tables 1 to Table 5 gives us the overall firm innovativeness scores shown in Table 6.

Table 6: Combined firm innovativeness score

\begin{tabular}{|l|l|l|l|l|l|l|l|l|l|l|l|l|l|}
\hline & F1 & F2 & F3 & F4 & F5 & F6 & F7 & F8 & F9 & F10 & F11 & F12 & $\bar{x}$ \\
\hline Total score & 78 & 69 & 88 & 62 & 89 & 45 & 64 & 68 & 16 & 53 & 65 & 59 & 63 \\
\hline
\end{tabular}

While the cumulative score of all the innovativeness values amounts to 95 , the item mean score of the firms surveyed and provided in Table 6 above, which is the overall innovativeness, was 63 , with about 58 per cent, or seven firms, scoring above the combined average innovativeness score. This means that an item mean score of 63 indicates about a 66 per cent level of overall innovativeness, which is a fairly good score. However, the non-technological innovativeness scores were higher than the technological scores (see Figure 2). There might be a number of reasons for this scenario. First, as indicated in Figure 2, three dimensions (organisational innovativeness, market innovativeness, and strategic innovativeness) were considered for the non-technological component, compared with the two dimensions (product and process innovativeness) used in the technological innovativeness component. Second, there were more items with a heavier weighting (the rating score) on the nontechnological component than in the technological component. For instance, the combined expected nominal score of the non-technological component was 53, compared with 42 for the technological component.

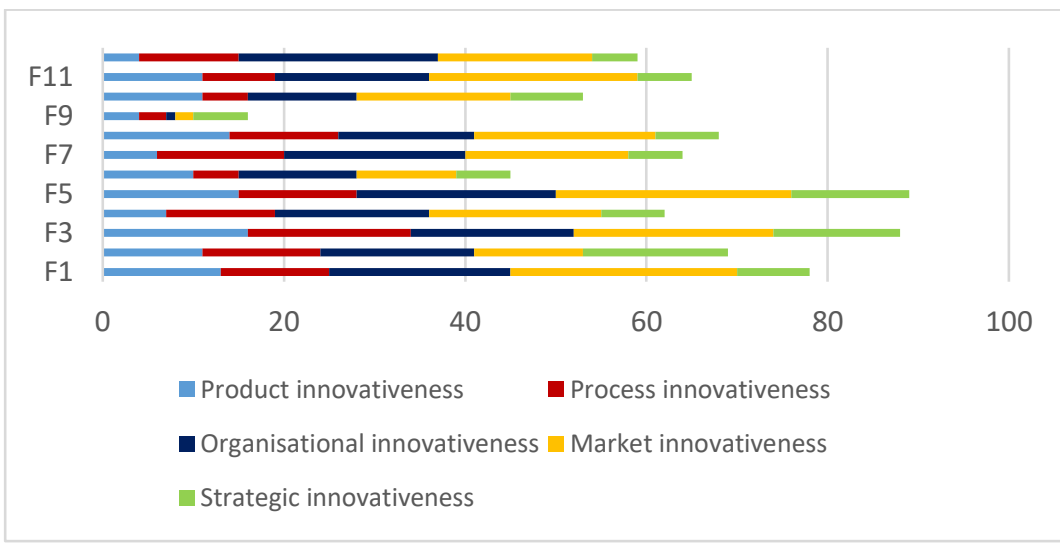

Figure 2: Overall firm innovativeness score (see online version for colour) 
Figure 3 shows a comparison of the mean technological innovativeness scores against those of the mean administrative innovativeness scores of the sampled firms. As indicated, most firms generally performed better in non-technological or administrative innovativeness than in technological innovativeness.

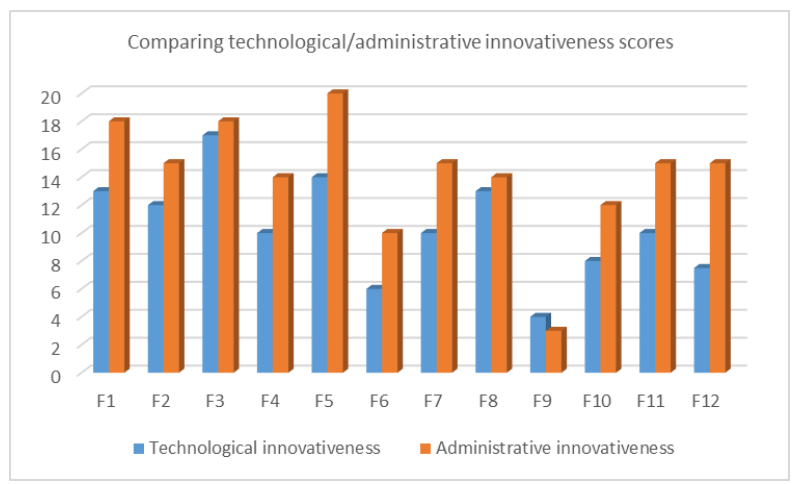

Figure 3: Comparing technological innovativeness and administrative innovativeness (see online version for colour)

\section{CONCLUSION}

\subsection{Concluding remarks}

The contemporary global business environment has become more and more dynamic, and often is turbulent and disruptive, if not harsh, with development times becoming shorter and shorter [20] [54]. Firms that can survive these contending environmental and competitive pressures are the ones that adapt to change [20]. Bubou and Amadi-Echedi [20] suggest that innovativeness is indicative of a firm's ability to adapt to change. The emphasis on technological innovativeness in this study was based on the arguments of Tsai, Chuang and Hsieh [55]. Whereas Tsai et al. [55] considered that both innovativeness categories can mutually enhance the adaptability of the enterprise to environmental changes and, by extension, could lead to higher organisational competitiveness, it was suggested that technological innovativeness appears to be of greater importance than administrative innovativeness (especially in high-tech industries). Of course, studies of management innovation confirm its significant impact on firms' financial performance [36]. Furthermore, technological innovativeness entails substantial in-house development and outputs that are characterised by higher degrees of uniqueness [56].

Evidence from the extant literature indicates that innovativeness contributes to competitive advantage both for firms and for the economy. Thus, managing the activities and processes that lead to innovativeness has become a strategic competitive point for the success of any organisation [43]. However, published works in the research context are scarce. This study thus attempted to fill that knowledge gap. Using group item means, we tried to measure the overall innovativeness of the sampled firms by aggregating the scores of the five innovativeness typologies: product/service innovativeness, process innovativeness, organisational innovativeness, market innovativeness, and strategic innovativeness. Overall, the results of our study reveal that the firms were innovative. Even though the sampled firms scored a little higher in product/service innovativeness than in process innovativeness, they generally performed better in administrative innovativeness than in technological innovativeness. These results are in line with the commonly held thinking that firms in developing regions are mostly process and administratively innovative [57].

\subsection{Limitations of the study}

The study was seriously hampered by the tedious process of obtaining permission from Nigeria's oil and gas industry's regulatory authority, and also by the seeming reluctance of petroleum firms to provide information to the researchers. For example, it took nearly one-and-a-half years for the first responding firm to contact the researchers to schedule an interview. Equally, the small sample size was a source of concern, as it may not be appropriate to draw any generalisable conclusions from the study. This challenge is not peculiar to this study. For instance, in a previous study by Yuan, Guo and Fang [58], a small sample size constrained the researcher's ability to test more complex 
relationships, particularly about contextual factors; this possibly hinders the statistical power of the analyses conducted and the generalisability of the findings [59]. The reality is that one cannot use a small sample survey like this to draw firm conclusions about the technological innovativeness of all petroleum firms in Nigeria. This sample might have generated a non-response bias that could diminish the generalisability of the conclusions of the study. This made the data-gathering phase of the research unnecessarily long. Another limitation is with the measurement scale itself. There were challenges with the current scoring system, which thus requires further refining. The measurements employed to assess the technological innovativeness of the firms also remain limited to subjective performance based on the perceptions of the respondents.

\subsection{Practical implications and recommendations for future study}

Apart from the above limitations, this study can generate key pointers to map out directions for further research, and issues to which policymakers, practitioners, and academia might wish to pay attention. The practical implications of this study are that its findings could enable companies to determine current levels of innovativeness that could further assist the firms to identify areas of focus in managing the innovation process. Equally, policymakers can gain insights from the findings to make evidence-informed decisions. Again, since innovativeness indicators in resource-intensive industrial sectors of Nigeria in particular, and in Africa generally, are scarce, this could be regarded as one critical step towards the development of a firm-level innovativeness index for the petroleum sector of Nigeria and, perhaps, in Africa too. Consequently, we recommend a detailed industry-wide innovativeness survey to determine the technological innovativeness of the petroleum sector.

\section{REFERENCES}

[1] Walsh, M., Lynch, P. \& Harrington, D. 2009. Innovativeness: A conceptual framework antecedents, dimensions, and outcomes. In: EuroCHRie, 22-24 October, Helsinki.

[2] Muller, A., Valikangas, L. \& Merlyn, P. 2005. Metrics for innovation: Guidelines for developing a customized suite of innovation metrics. IEEE Engineering Management Review, 33(4), pp. 66-72.

[3] Gilbert, D. 2007a. What drives and sustains firm innovativeness? In Proceedings of the 21 $1^{\text {st }}$ ANZAM Conference, Sydney: Australia. Available from: http://www.anzam.org/wp-content/uploads/pdfmanager/1849_GILBERTDAVID_389.PDF [accessed on 16 October 2017].

[4] Knowles, C.D. 2007. Measuring innovativeness in the North American softwood sawmilling industry. PhD dissertation submitted to the Department of Wood Science and Engineering, Oregon State University, United States.

[5] Dodgson, M. 2009. Asia's national innovation systems: Institutional adaptability and rigidity in the face of global innovation challenges. Asia Pacific Journal of Management, 26(3), pp. 589-609.

[6] Kaplan, M.D. 2009. The relationship between perceived innovativeness and emotional product responses: A brand oriented approach. Innovative Marketing, 5(1), pp. 39-47.

[7] Joshi, M. 2010a. Embracing competitive renaissance by steering innovation velocity. World Review of Entrepreneurship, Management and Sustainable Development, 6(1/2), pp. 149-162.

[8] Rhee, J., Park, T. \& Lee, D.H. 2010. Drivers of innovativeness and performance for innovative SMEs in South Korea: Mediation of learning orientation. Technovation, 30(1), 65-75.

[9] Borocki, J., Orcik, A. \& Cvijic, M. 2013. Measuring organisational innovativeness. In Bullinger, H.-J. and Spath, D. (eds), Engineering management - Challenges for the future, Novi Sad: Faculty of Technical Sciences, Stuttgart: Fraunhofer IAO, and Vienna: DAAAM International, pp. 147-164.

[10] Feimi, D., Kume, V. \& Pulaj, E. 2016. Macro environment and innovation in service sector: The evidence from Albanian context. European Journal of Sustainable Development, 5(2), pp. 137-142.

[11] Singh, L. 2007. Globalisation, national innovation systems and response of public policy. Munich Personal RePEC Archive (MPRA) Paper No. 641.

[12] Gilbert, D. 2007b. Firm innovativeness in SMEs: Lessons from Japan. International Journal of Organisational Behaviour, 12(1), pp. 126-143.

[13] Adams, R., Bessant, J. \& Phelps, R. 2006. Innovation management measurement: A review. International Journal of Management Reviews, 8(1), pp. 21-47.

[14] Boly, V., Morela, L., Assielou, N.G. \& Camargo, M. 2014. Evaluating innovative processes in French firms: Methodological proposition for firm innovation capacity evaluation. Research Policy, 43(3), pp. 608-622.

[15] Debreczeny, C., Uwe-Meyers, J., Schwartz, K. \& Katsikis, N. 2016. Challenges of introducing innovation measurement at businesses serving matured markets. Paper presented at the ISPIM Innovation Forum, 1316 March 12 - 13, Boston, MA: USA.

[16] Nigerian Bureau of Statistics. 2017. Nigerian Gross Domestic Product Report: Q4 2016. Abuja: Nigerian Bureau of Statistics.

[17] International Monetary Fund. 2017. Nigeria: 2017 Article IV Consultation - Press Release; Staff Report; and Statement by the Executive Director for Nigeria, IMF Country Report No. 17/80. 
[18] Nweze, N.P. \& Edame, G.E. 2016. An empirical investigation of oil revenue and economic growth in Nigeria. European Scientific Journal, 12(25), pp. 271-294.

[19] Erbas, B.C., Ali Fıkırkoca, A. \& Tuzcu, A. 2008. Innovativeness of manufacturing small and medium size enterprises in Turkish regional innovation system. Paper presented at the RSA Annual International Conference 2008 Regions: The Dilemmas of Integration and Competition, Prague, May 27-29.

[20] Bubou, G.M. \& Amadi-Echedu, J.E. 2016. Measuring the technological innovativeness of petroleum firms in an emerging economy like Nigeria. 2016 IEEE European Technology and Engineering Management Summit (E-TEMS), Frankfurt, pp. 1-8.

[21] Vafaei, M., Shakeri, F. \& Owlia, M.S. 2011. Study of innovativeness factors in Iranian automotive industry. In Proceedings of the 2011 International Conference on Industrial Engineering and Operations Management, Kuala Lumpur: Malaysia, pp. 1240-1243.

[22] Wang, C.L. \& Ahmed, P.K. 2004. The development and validation of the organisational innovativeness construct using confirmatory factor analysis. European Journal of Innovation Management, 7(4), pp. 303313.

[23] Hilmi, M.F. \& Ramayah, T. 2008. Market innovativeness of Malaysian SMEs: Preliminary results from a first wave data collection. Asian Social Science, 4(12), pp. 42-49.

[24] Duygulu, E. \& Özeren, E. 2009. The effects of leadership styles and organisational culture on firm's innovativeness. African Journal of Business Management, 3(9), pp. 475-485.

[25] Yusof, N.A. \& Abu-Jarad, I.Y. 2011. The organisational innovativeness of public- listed housing developers. International Journal of Human and Social Sciences, 6(2), pp. 109-113.

[26] Li, E.Y., Chen, J.-S. \& Huang, Y.-H. 2006. A framework for investigating the impact of IT capability and organisational capability on firm performance in the late industrialising context. International Journal of Technology Management, 36(1/2/3), pp. 209-229.

[27] Kristensen, F.S. 1998. Understanding learning in technological trajectories: Combining organisational integration and industrial dynamics. Available from: http://www.druid.dk/conferences/summer1998/conf-papers/kristensen.pdf [accessed on 19 June 2011].

[28] Gunday, G., Ulusoy, G., Kilic, K. \& Alpkan, L. 2011. Effects of innovation types on firm performance. International Journal of Production Economics, 133(2), pp. 662-676.

[29] Therin, F. 2003. Learning for innovation in new high technology ventures. Groupe ESC Grenoble, Working Paper No. SPR / WPS 03-07.

[30] Rogers, E.M. 1995. Diffusion of innovations. New York: The Free Press.

[31] Hurley, R.F. \& Hult, G.T.M. 1998. Innovation, market orientation, and organisational learning: An integration and empirical examination. Journal of Marketing, 62(3), pp. 42-54.

[32] Khasawneh, A.M. 2008. Concepts and measurements of innovativeness: The case of information and communication technologies. International Journal of Arab Culture, Management and Sustainable Development, 1(1), pp. 23-33.

[33] Kamaruddeen, A.M., Yusof, N-A. \& Said, I. 2009. A proposed framework for measuring firm innovativeness in the housing industry. International Journal of Organisational Innovation, 2(2) pp. 100-129.

[34] Chye, L.T., Tat, H.H., Osman, M.H.M. \& Rasli, A.M. 2010. Are managerial competencies a blessing to the performance of innovative SMEs in Malaysia? International Journal of Economics and Management, 4(1), pp. $120-136$.

[35] Liu, T.-H., Chu, Y.-Y., Hung, S.-C. \& Wu, S.-Y. 2005. Technology entrepreneurial styles: A comparison of UMC and TSMC. International Journal of Technology Management, 29(1/2), pp. 92-115.

[36] Kraśnicka, T., Głód, W. \& Wronka-Pośpiech, M. 2016. Management innovation and its measurement. Journal of Entrepreneurship, Management and Innovation, 12(2), pp. 95-122.

[37] OECD/EC. 2005. Oslo Manual: Guidelines for collecting and interpreting innovation data (3rd ed.). Paris: OECD Publishing.

[38] Garcia, R. \& Calantone, R. 2002. A critical look at technological innovation typology and innovativeness terminology: A literature review. The Journal of Product Innovation Management, 19(2), pp. 110-132.

[39] Dilek, T. 2009. Entrepreneurial team characteristics, environmental scanning and networking: Impact on organisational innovativeness in SMEs. Thesis (MSc). East Technical University, Turkey.

[40] Sawhney, M., Wolcott, R.C. \& Arroniz, I. 2006. The 12 different ways for companies to innovate. MIT Sloan Management Review, 47(3), pp. 74-81.

[41] Andrews, J. \& Smith, D.C. 1996. In search of marketing imagination: Factors affecting the creativity of marketing programmes for mature products. Journal of Marketing Research, 33(2), pp. 174-87.

[42] Atuahene-Gima, K., Li, H. \& De Luca, L.M. 2006. The contingent value of marketing strategy innovativeness for product development performance in Chinese new technology ventures. Industrial Marketing Management, 35(3), pp. 359-372.

[43] Lendel, V., Moravčíková, D. \& Latka, M. 2017. Organising innovation activities in a company. Procedia Engineering, 192, pp. 615-620.

[44] Pavlin, J. \& Černe, M. 2010. Achieving competitive advantage through innovativeness. In Proceedings of the Scientific Papers of the University of Pardubice, Series D, pp. 235-252.

[45] James, P.A., Knut, H., David, C.M., Harold, L.S. \& Andrew, T. 2008. Measuring innovation 2008: Squandered opportunities. A BCG senior management Survey Report. Available from: https://www.bcg.com/documents/file15302.pdf [accessed on 20 July 2017].

[46] Wong, G.Y.F. \& Fung, R.Y.K. 2005. Technological innovativeness and organisational culture in Hong Kong. Contemporary Management Research, 1(1), pp. 35-56. 
[47] Wu, J. 2007. Company innovativeness measurement: Development of an assessment tool to measure the innovation performance of companies. Thesis (MSc), Delft University.

[48] Jain, K., Siddiquee, Q. \& Singal, V. 2010. Measurement of innovativeness in an organisation using AHP. In Proceeding of the $10^{\text {th }}$ PICMET: Technology Management for Global Economic Growth, Phuket: Thailand, July 18-22.

[49] Stone, A., Rose, S., Lal, B. \& Shipp, S. 2009. Measuring innovation and intangibles: A business perspective. Institute for Defence Analyses, Working Paper: No. D-3704.

[50] Bigliardi, P., Colacino, P. \& Dormio, A.I. 2011. Innovative characteristics of small and medium enterprises. Journal of Technology Management and Innovation, 6(2), pp. 83-93.

[51] Laforet, S. \& Tann, J. 2006. Innovative characteristics of small manufacturing firms. Journal of Small Business and Enterprise Development, 13(3), pp. 363-380.

[52] Bubou, G.M. \& Amadi-Echendu, J.E. 2013. Schematic framework for measuring firm innovativeness in Nigeria's petroleum sector. In Proceeding of the XXIV ISPIM International Conference, Helsinki: Finland, June 16-19.

[53] Intarakumnerd, P. 2010. Proposed sets of supplementary science, technology and innovation indicators for latecomer economies at the firm and country levels. In Proceeding of the $8^{\text {th }}$ GLOBELICS International Conference, Kuala Lumpur: Malaysia, November 1-3.

[54] Moldaschl, M. 2007. Institutional reflexivity: An institutional approach to measure innovativeness of firms. Papers and reprints of the Department of Innovation Research and Sustainable Resource Management (BWL IX), Chemnitz University of Technology. Available from: http://archiv.tu-chemnitz.de/pub/2007/0180 [accessed on 19 June 2011].

[55] Tsai, M-T., Chuang, S-S. \& Hsieh, W-T. 2008. Using analytic hierarchy process to evaluate organisational innovativeness in high-tech industry. In Proceedings of the 39th Decision Sciences Institute (DSI) Annual Meeting, Baltimore: USA, November 22-25, vol. 1, pp. 433-438.

[56] O’Brien, K. 2016. Is newest always best? Firm-level evidence to challenge a focus on high-capability technological (product or process) innovation. Economics of Innovation and New Technology, 5(8), 747768.

[57] Hobday, M. 2005. Firm-level innovation models: Perspectives on research in developed and developing countries. Technology Analysis Strategic Management, 17(2), pp. 121-146.

[58] Yuan, X., Guo, Z. and Fang, E. 2014. An examination of how and when the top management team matters for firm innovativeness: The effects of TMT functional backgrounds, Innovation: Management, Policy and Practice, 16(3), pp. 323-342.

[59] Alpay, G., Bodur, M., Yilmaz, C. and Buiyuikbalci, P. 2012. How does innovativeness yield superior firm performance? The role of marketing effectiveness. Innovation: Management, Policy and Practice, 14(1), pp. 107-128. 


\section{SECTIONA: FIRM'S INNOVATIVENESS AND KNOWLEDGE MANAGEMENT PROCESSES}

\section{A.I. PRODUCT/SERVICE INNOVATION}

For questions 1 to 2, (Please, tick the one that applies)

1. How often does your company introduce a new product/service to the market? Once a year $\square$ Once in 2 years $\square$ Once in 3 years $\square$ Once in 4 years Once in 5 years $\square \quad$ Once in 10 years $\square$ None in the past 10 years $\square$

2. How frequent does your organizations modify the design of its product(s)/service(s)? Once a year $\square \quad$ Once in 2 years $\square \quad$ Once in 3 years $\square$ Once in 4 years $\square$ Once in 5 years $\square \quad$ Once in 10 years $\square$ None in the past 10 years $\square$

For questions $3-10$, tick the one that applies

\begin{tabular}{|c|c|c|c|c|}
\hline \multicolumn{2}{|c|}{ For questions $3-10$, tick the one that applies } & \multirow{2}{*}{ Yes } & \multirow{2}{*}{ No } & \multirow{2}{*}{$\begin{array}{c}\begin{array}{c}\text { Can't } \\
\text { say }\end{array} \\
\square \\
\square\end{array}$} \\
\hline 3. & $\begin{array}{l}\text { During the last two years did your firm introduce any new or significantly } \\
\text { improved goods/services? (Excluding the simple resale of new goods } \\
\text { purchased from other firms and changes of a solely aesthetic nature) }\end{array}$ & & & \\
\hline 4. & $\begin{array}{l}\text { Was the product/service mainly developed by your company or group of } \\
\text { companies? }\end{array}$ & & & \\
\hline 5. & Was the product/service developed with other firms or institutions & & & \\
\hline 6. & Or was it mainly developed by other firms or institutions & & & \\
\hline 7. & Where the products/services new to your firm & & & \\
\hline 8. & Where your products/services new to the market & & & \\
\hline 9. & $\begin{array}{l}\text { Products introduced to your firm during the last two years were products } \\
\text { unchanged or only marginally modified }\end{array}$ & & & \\
\hline 10. & $\begin{array}{l}\text { Using the definitions above, please give the percentage of your total turnover } \\
\text { in } 2012 \text { from: Products introduced during } 2011 \text { to } 2012 \text { that were new to your } \\
\text { market }\end{array}$ & & & \\
\hline
\end{tabular}

A.II: PROCESS INNOVATION

For questions 11-13, (Please, tick

11. How frequent does your company review its operating processes?

Twice a year $\square \quad$ Once a year $\square \quad$ Once in 2years $\square \quad$ Once in 3years $\square$
Once in 4years $\square \quad$ Once in 5 years $\square \quad$ None in the past 5years $\square$

12. How often does your company change its operating procedures?

Twice a year $\square \quad$ Once a year $\square \quad$ Once in 2years $\square$ Once in 3years $\square$

Once in 4years $\square$ Once in 5 years $\square$ None in the past 5 years $\square$

13. How often does your firm invest in new methods and firmware for its operations?

Twice a year $\square \quad$ Once a year $\square \quad$ Once in 2years $\square \quad$ Once in 3years
Once in 4years $\square \quad$ Once in 5 years $\square \quad$ None in the past 5years $\square$




\begin{tabular}{|l|l|l|l|}
\hline For questions 14-19, tick the one that applies & Yes & No & $\begin{array}{l}\text { Can't } \\
\text { say }\end{array}$ \\
\hline $\begin{array}{l}\text { 14. During the last two years did your company introduce new or significantly } \\
\text { improved methods of manufacturing or producing products/services? }\end{array}$ & $\square$ & $\square$ \\
\hline $\begin{array}{l}\text { 15. In the same period, did your company introduce any new or significantly } \\
\text { improved logistics or distribution methods for your inputs or products? }\end{array}$ & $\square$ & $\square$ & $\square$ \\
\hline $\begin{array}{l}\text { 16. During the years 2011 to 2012, did your company introduce new or } \\
\text { significantly improved supporting activities for your processes, such as } \\
\text { maintenance systems of operations for purchasing, accounting, or } \\
\text { computing? }\end{array}$ & $\square$ & $\square$ & $\square$ \\
\hline $\begin{array}{l}\text { 17. Was the process innovation mainly developed by your company or group } \\
\text { of companies? }\end{array}$ & $\square$ & $\square$ & $\square$ \\
\hline $\begin{array}{l}\text { 18. Was the process innovation developed with other firms or institutions? } \\
\text { 19. Or was it mainly developed by other firms or institutions? }\end{array}$ & $\square$ & $\square$ & $\square$ \\
\hline
\end{tabular}

\section{A.III: ORGANISATIONAL INNOVATION}

For question 20 , please, tick the one that applies.

20. How often does your firm implement changes to its organizational structure?

Twice a year $\square \quad$ Once a year $\square \quad$ Once in 2years $\square \quad$ Once in 3years $\square$

Once in 4years $\square \quad$ Once in 5 years $\square$ None in the past 5years $\square$

\begin{tabular}{|c|c|c|c|}
\hline For questions $21-26$, tick the one that applies & Yes & No & $\underset{\text { say }}{\text { Can't }}$ \\
\hline $\begin{array}{l}\text { 21. During the last two years did your firm introduce new business practices } \\
\text { for organising work or procedures (i.e. supply chain management, business } \\
\text { re- engineering, lean production, quality management, education/training } \\
\text { systems, etc.)? }\end{array}$ & & & \\
\hline $\begin{array}{l}\text { 22. In the same period, did your company introduce new methods of workplace } \\
\text { organisation for distributing responsibilities and decision making (i.e. first use } \\
\text { of a new system of employee responsibilities, team work, decentralisation, } \\
\text { integration or de-integration of departments, etc)? }\end{array}$ & & & \\
\hline $\begin{array}{l}\text { 23. During the years } 2011 \text { to } 2012 \text {, did your firm introduce new methods of } \\
\text { organising external re/ations with other firms or public institutions (i.e. first } \\
\text { use of alliances, partnerships, outsourcing or sub-contracting, etc.)? }\end{array}$ & & & \\
\hline $\begin{array}{l}\text { 24. Were these organisational innovations mainly developed by your } \\
\text { company or group of companies? }\end{array}$ & $\square$ & & \\
\hline $\begin{array}{l}\text { 25. Were they developed with other firms or institutions (including } \\
\text { consultants)? }\end{array}$ & & & \\
\hline 26. Or were they mainly developed by other firms or institutions (including & $\square$ & $\square$ & \\
\hline
\end{tabular}




\begin{tabular}{|c|c|c|c|c|}
\hline $\begin{array}{l}\text { For the next five questions, rank the level importance of the } \\
\text { statement(s) to your firm. } \\
\text { How important were each of the following effects on your } \\
\text { enterprise's organisational innovations introduced during } \\
\text { the two years } 2011 \text { to 2012? (High, medium, low or not }\end{array}$ & High & Medium & Low & $\begin{array}{l}\text { Not } \\
\text { relevant }\end{array}$ \\
\hline 27. Reduced time to respond to customer or supplier needs & $\square$ & $\square$ & $\square$ & $\square$ \\
\hline 28. Improved quality of your goods or services & $\square$ & $\square$ & $\square$ & $\square$ \\
\hline 29. Reduced costs per unit output & $\square$ & $\square$ & $\square$ & $\square$ \\
\hline $\begin{array}{l}\text { 30. Improved employee satisfaction and/or lower } \\
\text { employee turnover }\end{array}$ & $\square$ & $\square$ & $\square$ & $\square$ \\
\hline 31. Improved communication or information sharing & $\square$ & $\square$ & $\square$ & $\square$ \\
\hline
\end{tabular}

\section{A.IV: MARKET INNOVATION}

32. How often does your company implement changes to marketing concepts? f) Once in 5 years $\square$, Once a year $\square$ c) Once in 2 years $\square$ d) Once in 3 years $\square$ e) Once in 4 years

33. How many new markets (previously untapped frontiers) has your firm entered in the past five years? a) More than five in the past 5 years $\square$ b) Five in the past $5 y$ years $\square$ c) Four in the past 5 years $\square$ d) Three in the past 5 years $\square \quad$ e) Two in the past 5years $\square$ f) One in the past 5years $\square$

\begin{tabular}{|c|c|c|c|}
\hline For questions $34-40$, tick the one that applies & Yes & No & $\underset{\text { say }}{\text { Can't }}$ \\
\hline $\begin{array}{l}\text { 34. During the last two years did your firm introduce new significant changes to the } \\
\text { packaging of goods or services (exclude changes that only alter the product's } \\
\text { functional or user characteristics)? }\end{array}$ & & & \\
\hline $\begin{array}{l}\text { 35. In the same period, did your company introduce new media or techniques for } \\
\text { product promotion (i.e. the first time use of a new advertising media, fundamentally } \\
\text { new brand to target new markets, introduction of loyalty cards, etc?) }\end{array}$ & & & \\
\hline $\begin{array}{l}\text { 36. During the years } 2011 \text { to } 2012 \text {, did your firm introduce new methods for product } \\
\text { placement or sales channels (i.e. first time use of franchising or distribution } \\
\text { licences, direct selling, exclusive retailing, new concepts for product presentation, } \\
\text { etc.)? }\end{array}$ & & & \\
\hline $\begin{array}{l}\text { 37. During the same period, did your firm introduce, new methods of pricing goods } \\
\text { or services (i.e. first time use of variable pricing by demand, discount systems, etc.) }\end{array}$ & & & \\
\hline $\begin{array}{l}\text { 38. Were these marketing innovations mainly developed by your company or group } \\
\text { of companies? }\end{array}$ & & & \\
\hline 39. Were they developed with other firms or institutions (including consultants)? & & & \\
\hline $\begin{array}{l}\text { 40. Or were they mainly developed by other firms or institutions (including } \\
\text { consultants)? }\end{array}$ & & & \\
\hline
\end{tabular}




\begin{tabular}{|c|c|c|c|c|}
\hline $\begin{array}{l}\text { For the next five questions, rank the level importance of the statement(s) to } \\
\text { your firm. } \\
\text { How important were each of the following effects on your enterprise's } \\
\text { organisational innovation introduced during the two years } 2011 \text { to } 2012 \text { ? } \\
\text { (High, medium, low or not relevant) }\end{array}$ & High & Medium & Low & $\begin{array}{c}\text { Not } \\
\text { relevant }\end{array}$ \\
\hline 41. Increased or maintained market share & & & & \\
\hline 42. Introduced products to new markets or customer groups & & & & \\
\hline 43. Reduced costs per unit output & & & & \\
\hline 44. Increased visibility of products or business & & & & \\
\hline 45. Improved ability to respond to customer needs & & & & \\
\hline
\end{tabular}

\section{A.VI: STRATEGIC INNOVATION}

46. Does your firm has a written strategic plan? Yes $\square \quad$ No $\square$

47. How often does your firm review its vision, mission and strategic objectives?
Once a year $\square$
Once in 2years $\square$
Once in 3years $\square$ Once in 4years $\square$

Once in 5years $\square \quad$ Once in 10years $\square \quad$ None in the past 10years $\square$

48. How often has your company initiated new competitive strategies within the past five years?
a) Once a year $\square$
b) Once in 2years $\square$
c) Once in 3 years
d) Once in 4years $\square$
e) Once in $5 y e a r s$
g) Once in 10years
h) None in the past 10years $\square$

49. How many new strategies have your company introduced to effect change (s) in its overall corporate strategy in the past five years? a). More than five in the past $5 y e a r s ~ \square$

5years $\square \quad$ c) Four in the past 5 years $\square$ d) Three in the past 5years $\square$

b) Five in the past

e) Two in the past $5 y$ ears $\square$ f) One in the past 5years $\square$ g) None in the past $5 y$ years

\section{B.I: INNOVATIONS INTRODUCED OR ADOPTED}

Please, kindly list the innovations your company has introduced or adopted within the last five years (you may use extra sheet of paper if needed)

50. Product innovations

51. Service innovations

52.Process innovations

53. Organis ational (Managerial) innovations

54. Marketinnovations 